\title{
TEXTO NO CONTEXTO: UMA PROPOSTA ESCRITURAL
}

\author{
Girlene Lima Portela *
}

\begin{abstract}
Resumo: Ao escrevermos, devemos ter em mente que um texto se constrói a partir de um modelo de situação, integrando-se o conteúdo semântico a uma estrutura de conhecimentos ou esquemas, o que é balizado pelas ideias ou proposições em torno das quais cada um dos significados particulares encontra um sentido, uma unidade e uma coerência global. Buscando contribuir para a discussão acerca do que vem a ser um texto eficiente, o presente artigo trará uma experiência vivenciada em uma de minhas turmas de língua portuguesa, a fim de contribuir para a ampliação das possibilidades de trabalho com textos em sala de aula.
\end{abstract}

Palavras-chave: Textualização. Produção escrita. Relato de Experiência.

\begin{abstract}
When we write, we must bear in mind that a text is constructed from a model of situation, integrating the semantic content to a structure of knowledge or schema, which is driven by ideas or propositions around which each of particular meanings creates a sense, a unity and an overall consistency. Seeking to contribute to the discussion about what is to be an efficient text, the present article will bring an experience in one of my classes of Portuguese language, in order to contribute to the expansion of the possibilities of working with texts in the classroom.
\end{abstract}

Keywords: Textualization. Written Production. Experience Report.

\section{A importância da leitura para a melhoria da qualidade escritural}

Concebida como uma atividade cognitiva, a leitura nos faculta o equilíbrio e a eficiente utilização de informações. Quando lemos, o fazemos para conhecer ideias alheias, a fim de refutá-las ou aderir-lhes o espírito, o que cria em nós, leitores, um arsenal de diferentes possibilidades de propostas e de sugestões. De posse desse importante arsenal, podemos melhor estruturar nossas ações pedagógicas, no sentido de desencadear, no nosso aluno, o prazer de ler e de registrar suas impressões de viagem em diferentes textos/gêneros.

Quando lemos, além de ampliarmos nossa visão das ações que nos circundam, abrimos novas possibilidades de criação/reprodução de estilos, ampliação do léxico, abertura para novas apreensões ou até mesmo refutação de paradigmas, o que nos torna, enquanto seres no mundo, mais preparados para a construção do nosso eu, refletindo nos nossos discursos nossa bagagem linguístico-cultural. Tais ações nos permitem desenvolver reflexões discursivas, por meio de diferentes gêneros textuais, com diferentes estratégias de busca do nosso leitor, a fim de estabelecer uma cumplicidade, uma adesão à visão da realidade que nos cerca.

Nessa linha de pensamento, temos um conceito de texto que reafirma a importância dos elementos que compreendem a leitura, ou seja,

O texto pode ser considerado um conjunto de pistas, representadas por elementos linguísticos de diversas ordens, selecionados e dispostos de acordo com as virtualidades que cada língua põe à disposição dos falantes, no curso de

\footnotetext{
* Mestre em Linguística e Doutora em Educação. Professora plena da Universidade Estadual de Feira de Santana. Membro do EAPLA (ANPOLLL). Email: falecom@girleneportela.com.br.
} 
uma atividade verbal, de modo a facultar aos interactantes não apenas a produção de sentidos, como a fundear a própria interação como prática sociocultural. (KOCH, 1997, p. 26).

Nessa proposição, Koch (1997) nos leva a refletir acerca da fundamental relação entre leitura e escrita, pois ao produzirmos um texto, o fazemos a partir das pistas que adquirimos em diferentes leituras sob vários níveis que fazemos ao longo da vida.

Para concluir essa seção inicial, convoco Leffa (1996) para nos brindar com sua visão acurada acerca do que vem a ser leitura, englobando as discussões engendradas até então.

A leitura é basicamente um processo de representação. Como esse processo envolve o sentido da visão, ler é, na sua essência, olhar para uma coisa e ver outra. A leitura não se dá por acesso direto à realidade, mas por intermediação de outros elementos da realidade. Nessa triangulação da leitura o elemento intermediário funciona como um espelho; mostra um segmento do mundo que normalmente nada tem a ver com sua própria consistência física. Ler é portanto reconhecer o mundo através de espelhos. Como esses espelhos oferecem imagens fragmentadas do mundo, a verdadeira leitura só é possível quando se tem um conhecimento prévio desse mundo (LEFFA, 1996, p.10).

Assim, a fim de adentrarmos um pouco mais nesse universo, apresentaremos, a seguir, uma seção que trata do texto enquanto lastro teórico da minha proposta para uma mudança no hábito do professor que visa interferir positivamente na vida de seus alunos, auxiliando-os numa maneira de ver o mundo munidos de espelhos, como propôs Leffa (1996).

\section{$2 \mathrm{O}$ texto no contexto acadêmico: as contribuições das correntes teóricas}

\section{1 ( $\operatorname{Re})$ Conceituando texto}

Produzir texto é uma atividade que exige múltiplas capacidades, dentre as quais aquela em que o autor se antecipa ao seu interlocutor, visto que a compreensão de um texto supõe que o leitor identifique as informações importantes para construir uma representação de base, associando-as às argumentações do autor. Assim, a identificação das informações importantes está ligada ao fato de o leitor apreciar (ou não) as informações contidas no texto, que deve apresentar argumentos claros, numa integração hierarquizada de diferentes objetivos. Na seção seguinte, retomaremos essas habilidades para melhor explicitá-las, com exemplificações.

Nessa perspectiva, ao se produzir um texto deve-se ter em mente que este se constrói a partir de um modelo de situação, integrando-se o conteúdo semântico a uma estrutura de conhecimentos ou esquemas, o que é balizado pelas ideias ou proposições em torno das quais cada um dos significados particulares encontra um sentido, uma unidade e uma coerência global. Ou o que alguns autores concebem como macro e micro estruturas.

Teun van Dijk (1978) amplia essas informações, falando das duas dimensões a serem consideradas na produção de um texto, o que vale também para a leitura deste, quais sejam: $a$ dimensão pragmática (macro atos de fala/intenções/objetivos/atualização/situações 
comunicativas); a dimensão global (modelos cognitivos /superestruturas) e a dimensão linguística de superfície (marcas sintático-semânticas).

Já na concepção de Leffa (1996, p. 25) "para compreender um texto devemos relacionar os dados fragmentados do texto com a visão que já construímos do mundo. Todo texto pressupõe essa visão do mundo e deixa lacunas a serem preenchidas pelo leitor". Comungo dessa proposição de Leffa, pois sem o preenchimento dessas lacunas a compreensão das mensagens veiculadas por determinada enunciação não é possível.

Mas, o que vem a ser texto? Segundo Greimas e Courté (1989), toda manifestação, seja ela uma pintura ou um balé, pode ser considerada um texto. Nessa perspectiva, um texto seria um conjunto de múltiplas formas de representação ou códigos semióticos que, através de meios próprios e independentes, realizam sistemas de significados. Já no dizer de Charles (1995), um texto não existe "fora do olhar que lhe dirijo, fora da experiência que tenho, fora das operações que faço sobre ele para que ele se torne precisamente um texto". (CHARLES, 1995, p. 40 apud ADAM, 2011, p.65). Nesse contexto, um texto

resulta de nossas ações linguísticas (conhecimentos gramaticais e enciclopédicos), cognitivas (conhecimentos guardados a curto, médio e longo termo) e sociais (contratos e convenções determinados por uma dada sociedade), as quais estão envolvidas em sua organização (pesquisa de ideias), produção (planejamento), compreensão (análise e síntese) e funcionamento (intenção/aceitação) no meio social (PORTELA, 2010, p. 25).

Nessa linha de pensamento, podemos dizer que qualquer texto que combine vários modos semióticos pode ser visto também como uma instanciação do sistema semiótico e reflete as escolhas feitas pelo seu autor, dentro do contexto onde é produzido (HALLIDAY; HASAN, 1989).

Assim, além das informações e das intenções, ao produzirmos um texto, não devemos perder de vista sua unidade, sua organização, seu engendramento, o que se dá por meio dos fatores textuais/discursivos descritos, a seguir.

\section{A importância dos fatores textuais/discursivos para a melhoria da escrita}

Como vimos na seção anterior, um texto é toda manifestação (GREIMAS, 1989) ou ele "não existe fora da experiência que tenho (...)" (CHARLES, 1995, p. 40) ou ainda "representa um conjunto de pistas (...) de acordo com as virtualidades que cada língua põe à disposição dos falantes" (KOCH, 1997).

Em um dos meus artigos (2004), conceituei texto como tudo aquilo que comunica algo (...). Se considerarmos todas essas propostas, podemos sintetizar tais conceitos dizendo que um texto seria um conjunto de pistas que nos guiam para a compreensão da(s) mensagem(ns) nele veiculada(s), com o propósito de nos levar a refletir acerca do nosso lugar no mundo. Entretanto, apesar de haver muitas conceituações para o texto, não podemos esquecer que este se organiza através de uma textualidade, que vem a ser a materialização e/ou predomínio de alguns elementos essenciais à clareza, precisão e objetividade do discurso, estabelecendo uma relação de 
envolvimento entre o texto e o usuário em uma determinada situação comunicativa, uma vez que ela é responsável pela unidade semântica, pelo sentido do texto, envolvendo não só aspectos lógicos, mas também pragmáticos, cognitivos, culturais e interacionais, os quais devem ser recuperados na leitura (cf. PORTELA, 2012).

Como vimos, a partir da conceituação de texto, a base de qualquer processo de interação é a discursividade, visto que o seu ponto de partida está centrado num certo acordo entre interactantes. Assim, o processo argumentativo é fruto de um acordo prévio entre o falante/escritor e o seu interlocutor/leitor. Esse acordo, segundo Perelman (1977), exprime-se nas premissas da argumentação.

Assim, sendo a argumentação um discurso que se insere numa troca interlocutória recíproca ao nível da sociabilidade, terá de pressupor, ou partir de um acordo sobre o que quer que seja, o que foi matéria de análise do linguista americano Grice, o qual defende o princípio de cooperação $^{1}$ ou Teoria Inferencial das Implicaturas. Para ele, quando dois indivíduos estão dialogando, existem leis implícitas que governam o ato comunicativo. Isso significa que, mesmo inconscientemente, os interlocutores trabalham a mensagem linguística de acordo com certas normas comuns que caracterizam um sistema cooperativo entre eles, para que as informações possam ser trocadas o mais univocamente possível. Embora inicialmente as propostas tanto de Perelman quanto de Grice se adequassem à conversação face a face, tais premissas podem ser observadas principalmente no texto escrito, especialmente se considerarmos que, na "falta" física do nosso interlocutor/leitor, devemos primar ainda mais pela intencionalidade, visando uma aceitabilidade satisfatória, visto que queremos sempre "pegar nosso leitor pela mão", como propunha Barthes em seu célebre livro sobre leitura, intitulado Le plaisir tu texte.

Nessa perspectiva, um texto cujo recurso empregado é a oposição ou contraste visa a explicar fatos, ideias, comparando-se e apontando-lhes as diferenças, o que implica a descrição dos elementos comparados, apontando os contrastes e o desenvolvimento de ideias, o que caracterizaria o texto chamado de "dissertativo" nos concursos vestibulares. Mas como dissertar sem conhecer a fundo a temática a ser tratada? Nossos estudantes dominam a arte da escrita? Eles sabem o que vem a ser um texto? Conhecem sua importância?

Buscando auxiliar os professores a melhor conhecerem as teorias que embasam os manuais escolares - mas que sequer contam com a ética da maioria dos seus autores em ao menos atribuir a devida autoria dos postulados que servem a explicar a mágica da didatização apresento, na próxima seção uma proposta de ensino-aprendizagem de leitura/escrita.

Após conhecermos a base teórica que deu suporte aos meus estudos nesses últimos treze anos, apresento, a seguir, minha contribuição acadêmica, uma vez que estou cônscia da importância da difusão dos meus conhecimentos em prol da educação, pelo menos na parte que me compete, o ensino-aprendizagem da escrita, a fim de melhor auxiliar professores e alunos a se sentirem sujeitos/atores de suas atividades de produção textual. Para tanto, ilustro minha proposição a partir de uma experiência como docente em uma disciplina que tem como mote o estudo do texto em suas variadas dimensões.

\footnotetext{
${ }^{1}$ O Princípio Cooperativo de Grice sugere um conjunto de quatro máximas para que uma comunicação seja bem sucedida. São elas: Máxima de Quantidade, que garante que só se deve dar informações em quantidades suficientes; Máxima de Qualidade, que diz que só se deve afirmar aquilo que for verdade; Máxima da Relevância, que expressa que o enunciador deve ser relevante e; Máxima de Modo, que afirma que se deve ser claro nas enunciações.
} 


\section{Desvelando nossa contribuição: uma proposta de ensino-aprendizagem}

Ao realizar atividades em minhas aulas de língua portuguesa, seja para o Curso de Letras, seja para cursos diversos (Matemática, Odontologia, Economia, Contábeis, etc..), sempre primei pela leitura e produção textual, visando sempre à ementa da disciplina, mas ao mesmo tempo tentando perseguir a proposta epistemológica da área do Conhecimento (Ciências Humanas, Ciências Sociais aplicadas, etc), a fim de desmitificar a ideia de que "português é difícil", respeitando ao máximo tais epistemologias. Muitas seriam as experiências que eu poderia relatar no presente documento, mas dado o tempo que tenho para a sua produção, bem como em respeito ao número de páginas exigido, limitar-me-ei a uma última experiência vivenciada no ano de 2012, numa turma de Letras com espanhol, onde ministro a disciplina Língua Portuguesa VI, cuja ementa é "Exame da Diversidade Textual".

Em meus cursos, sempre busco aliar a teoria à pratica, solicitando, após os cursos expositivos, que os estudantes elaborem uma aula para uma determinada série, a fim de trabalhar um certo fator de textualidade, para verificar se o assunto foi apreendido a ponto de acontecer uma transposição didática de qualidade. Para tanto, dou um modelo de plano de aula, incentivando o estudante a sempre planejar suas aulas, para demonstrar segurança e organização aos seus alunos. Antes de iniciar a aula, eles devem me apresentar o plano de aula para que eu constate a adequação, a relevância e a pertinência do conteúdo apresentado, verificando também se este está consoante as exigências do gênero plano de aula. Outro objetivo que viso alcançar com a solicitação do plano é preparar os estudantes para seleções e concursos, o que tem sido muito proveitoso, segundo os estudantes.

Numa dessas oportunidades, pude constatar como a proposição de alguns dos linguistas citados anteriormente é verdadeira, visto que um texto estabelece sempre uma relação de envolvimento entre os interactantes, seja no nível da adesão, seja no nível de refutação, a partir das concepções de mundo bem como dos conhecimentos linguístico-discursivos de cada interlocutor, o que foi observado durante uma das minhas aulas, no mês de dezembro de 2012, quando os grupos apresentavam seminários acerca de alguns fatores de textualidade.

Dentre as propostas de apresentação, surgiu, a partir de uma orientação de um dos grupos, as seguintes produções acerca da apresentação de alguns objetos, sobre os quais os colegas deveriam produzir um texto descritivo em, no máximo, cinco minutos. Após a apresentação de uma bela caixa, aguçando a curiosidade dos colegas, as estudantes apresentadoras do seminário retiraram dessa misteriosa caixa, inicialmente, um relógio de pulso e pediu que as duplas formadas fizessem uma descrição daquele objeto, surgindo os seguintes textos:

a) Relógio de Pulso (Autores: Alex Santana e Thais Vinhas).

Ele mede a hora e se deixa levar pelo tempo. De traços esguios e pontos brilhantes, ele informa os seus compromissos, ida e vinda de toda uma vida. Em suas 24 horas de tic-tac, ele te acorda, te lembra das refeições, da virada da noite e do ano que vai chegar. Meu relógio, meu carinho em meu pulso sempre está.

b) Leilão (Autoras: Melline Lima e Isabelle Silva). 
Leiloamos esse relógio usado pelo Faustão na estréia do Domingão. Ele possui um fundo branco com números em prata, tem visor com um design moderno e prático, adornado com uma moldura cravejada de diamantes precisamente lapidados para realçar a beleza desse Rolex tão valioso. Sua pulseira é feita com couro marroquino para proporcionar maior conforto ao sortudo vencedor desse leilão.

Já no título dessas produções, vemos a forma diversa como cada dupla concebeu a orientação, atribuindo-lhe sentidos totalmente diferentes, embora o objeto central fosse o mesmo. No início dos textos vemos, de um lado, uma menção literal ao objeto relógio, seguida de licença poética para melhor caracterizá-lo. De outro lado, temos um fator surpresa, que é a utilização de informações midiáticas, relacionadas a programas televisivos, a exemplo de um popular, veiculado aos domingos e outros que se utilizam desse programa dominical para parodiar os exageros do apresentador, célebre por suas interrupções e comentários, por vezes inadequados. No entanto, apesar do fator surpresa inicial, logo os autores retomam a orientação de descrever o objeto, se aproximando do texto 1.

Em seguida, é retirado da caixa um colar, sobre o qual os colegas deverão também descrevê-lo, surgindo esses resultados:

c) (Sem título) (Autora: Carine Andrade).

No porão de uma velha casa do sertão de Tucano, encontraram um porta-jóias, que datava ser do séc. XVI. Dentro dele tinha um colar, encadeado de anéis dourados. Absurdo! Que brilho magnífico! Irradiava uma luz que remeteu-nos à liberdade do ser. Sua cor dourada proporcionou a perspectiva de como são os colares antigos.

d) (Sem título) (Autoras: Melline Lima e Isabelle Silva)

Procura-se um belíssimo colar de ouro perdido durante o furacão Sandy.

Prometemos uma gratificação ao bondoso ser que o encontrar. O colar possui um grande valor financeiro, porém mais do que isso, ele tem uma grande importância afetiva. Ele foi dado á minha mãe pelo meu pai, que por sua vez o ganhou de presente da rainha Elisabeth, enquanto trabalhava como motorista da família Real.

Por favor, quem encontrar nos devolva. Estamos desolados!

Nessa segunda produção, nos chama a atenção a falta de título, pois a atividade já não apresenta tanta novidade e, aparentemente, os autores querem ganhar tempo, desenvolvendo o texto. Na produção 1, a autora se vale de informações sobre o local de nascimento de um dos colegas e faz uma junção de contextos surpreendentes, pois apresenta um local árido, esquecido das autoridades mas com uma riqueza pessoal incalculável: um colar preciosíssimo! Já no texto 2 temos também a menção ao valor monetário e afetivo do objeto, mas dessa feita não se obtém informações sobre o local onde se passa a narrativa, visto que o furacão Sandy devastou muitas cidades. Temos também menção a um universo totalmente avesso ao sertão baiano: a dinastia da realeza londrina, contrastando radicalmente com o cenário da primeira produção.

Ainda da bela e adornada caixa eis que surge um objeto muito peculiar: uma fita adesiva, sobre a qual as duplas deveriam também descrevê-lo, num desafio ainda maior, dado às 
limitações que, a princípio tal objeto encerrava. Contudo, as produções surpreendem pelo nível de criatividade e novamente pelas concepções do objeto, que desembocaram, em ambos os casos na busca pela intervenção do leitor, com a utilização clara de intertextos diversos, "brincando" com as informações, como pode ser constatado abaixo:

\section{Texto 1: (sem título) (Autora: Maria Otacília Morais)}

O que é o que é?

Sou pequeno e redondo

Dou muitas voltas e me escondo

Atrás de plástico e tenaz.

Muito útil e eficaz

Sirvo para colar partes como se fosse uma tenaz

Transparente e discreto

Ajudo sempre, sou esperta.

Pois minha função é colar

O que por natureza naturalmente

Não se faz.

Colo, logo existo

Eu sou ...?

Texto 2: Propaganda (Autora: Carol Duarte).

Compre já a sua Fita adesiva multi-uso F.C.C adesiveitor. Já Fecha, cola e cala.

Ela simplesmente resolve vário dos seus problemas do dia-dia. Fecha recipientes abertas. Cola aquele vaso muito chique que aquele seu sobrinho quebrou, cola aquela linda travessa que a sua vizinha pediu emprestada, mas, devolveu quebrada e principalmente, vai colar a boca daqueles vizinhos fofoqueiros e também da sogra implicante, da colega invejosa.

Ligue já: 0800-000-5555 fale com uma das nossas atendentes do Shop Universitário e peça a sua.

No cartão ou boleto bancário.

Ela está a venda também nas melhoras lojas especializadas da cidade.

$\mathrm{Ou}$

Ligue e compre com preço especial e ganhe o Frete grátis.

Nessas produções, vemos, no caso 1, a falta intencional do título, pois a autora contava com o fator "adivinhação", surpresa, convidando o leitor a tentar descobrir, através de seu engenho descritivo, pela escolha criteriosa das palavras, do que se tratava. No caso 2, temos um título curto, sem muitas informações, também com o intuito de convidar o leitor a descobrir, no desenvolvimento, do que tratava a propaganda.

Nas atividades acima aventadas e comentadas, mesmo en passant, podemos constatar a maneira como o produtor de um texto, apesar de receber as mesmas informações/instruções 
imprime, na sua produção, suas experiências pessoais, suas concepções de mundo e, mais que isso, sua criatividade com a utilização do que chamo de exteriorização de nossas ações enquanto seres no mundo, o que corrobora as teorias de Greimas e de Charles, apresentadas no início da seção anterior. Grosso modo, podemos dizer que dentre todos os aspectos textuais/discursivos utilizados pelos autores dos textos em tela o que mais se destaca é a criatividade muito comum em nossos estudantes e que, infelizmente a escola não tem sabido valorizar em seus testes padronizados.

Nessa perspectiva, convidamos as pesquisadoras Ilma Nogueira (UERJ) e Márcia Maria (UFF), no texto intitulado Linguística textual da teoria para a prática em sala de aula para corroborarem nossa premissa, quando estas dizem que

Cada pessoa possui uma representação interior de memórias associativas, de pensamentos e linguagens simbólicas. A experiência de viver dá origem às potencialidades criativas dos homens (...). Ao trabalhar o texto, os alunos não só desenvolvem a interpretação, mas também adquirem a compreensão de sua funcionalidade diante da variação de potencialidades de ocorrências representativas, de acordo com sua relação com a identidade do que está representado. O caráter infinito da linguagem constitui o sistema das palavras criadas para expressarem num instante mágico as emoções sentidas através da escrita e da fala.

Ao acessar essa citação, imagino como temos perdido a chance de melhorar a capacidade criadora dos nossos estudantes, ao limitarmos nossas aulas ao nível de intermináveis leituras de teorias e discussões que não levam a nada, ou melhor: levam a uma prova que nada prova!

\section{Modelo de Ensino-aprendizagem de leitura/escrita: base componencial}

A fim de melhor explicitarmos o valor da troca de experiências, quando damos oportunidade aos nossos alunos de serem de fato sujeitos de suas aprendizagens, tomemos por base mais uma vez os textos produzidos por meus estudantes, discutidos na seção anterior, para apresentar os fatores de textualidade, um dos componentes do modelo do meu plano de ensinoaprendizagem de leitura/escrita.

Iniciemos pela intencionalidade, pois antes de produzirmos um texto devemos ter clara a nossa intenção: informar, divertir, argumentar, etc. Já que esse fator teve uma conceituação inicialmente filosófica, recuperado por Franz Brentano da Escolástica, uma subcategoria dentro da filosofia medieval para definir o estatuto da consciência, qualificada por estar dirigida para algo, ou de ser acerca de algo, possuída pela maior parte dos nossos estados conscientes. $\mathrm{O}$ termo foi mais tarde usado por Edmund Husserl, que defendeu que a consciência é sempre intencional ${ }^{2}$.

No âmbito da Linguística Textual, esse fator refere-se ao modo como os emissores usam textos para perseguirem e realizarem suas intenções. Beaugrande e Dressler (1981) afirmam que,

\footnotetext{
${ }^{2}$ Fonte Wikipédia.
} 
para uma manifestação linguística se constituir num texto, é necessário que haja a intenção do locutor de apresentá-la e dos alocutários de aceitá-la como tal. Assim, a produção de textos funciona como ação discursiva relevante para atingir determinados objetivos. No sentido amplo, a intencionalidade abrange, conforme esses autores "todas as maneiras como os interlocutores usam os textos para perseguir e realizar suas intenções” (BEAUGRANDE; DRESSLER, 1981, p. 116). Assim, a intencionalidade está ligada diretamente à aceitabilidade, não sendo possível dissociá-las, pois o texto vincula-se às circunstâncias em que interagimos com ele e sua configuração aponta a utilidade e a pertinência dos nossos objetivos (PORTELA, 2004).

A aceitabilidade está relacionada à atitude do receptor frente aos textos, se tem relevância ou utilidade para ele. Tal princípio depende da intencionalidade, relacionada à atitude do autor que busca apresentar um texto coerente e coesivo. O remetente tenta criar um texto que tenha sentido e o destinatário o recebe como algo com sentido (BEAUGRANDE; DRESSLER, 1981, p. 116).

De acordo com Hayes e Flower (1980), para escrever/entender um texto é preciso que se tenha uma meta, a qual deve estar intimamente ligada à textualidade, pois os fatores nelas expressos servirão para um planejamento e uma execução que leve a um bom resultado. Nessa perspectiva, o escritor precisa se ater aos princípios e ainda se antecipar ao seu leitor na formulação de eventuais dúvidas, revisando seu texto para eventuais correções, pois ler/escrever um texto pode ser comparado a uma resolução de problemas, uma vez que se deve planejar o modo pelo qual o texto escrito será lido. (PORTELA, 2010)

Vejamos como tais fatores foram utilizados pelos meus estudantes na atividade sobre os objetos relógio, colar e fita adesiva: Com o intuito (intencionalidade) de defender a importância da informação adequada, para a produção de um texto eficaz, as alunas demonstraram tais objetos e solicitaram que os colegas produzissem um texto destacando suas características. Após compreenderem as informações dadas acerca da produção, houve uma aceitabilidade por parte dos colegas, que prontamente produziram o texto, demonstrando suas habilidades escriturais e suas bagagens culturais, visto que todos viram o mesmo objeto, mas cada dupla optou por contextualizá-lo de uma forma diferente, a depender dos conhecimentos enciclopédicos e das experiências individuais e também coletivas, coadunando a intencionalidade tanto das orientadoras da atividade quando dos escritores, que imprimiram também à produção sua intencionalidade, buscando perseguirem também a aceitação por parte dos interlocutores/interactantes ${ }^{3}$.

Texto 1: (...) Em suas 24 horas de tic-tac, ele te acorda, te lembra das refeições, da virada da noite e do ano que vai chegar (...). (Alex e Thaís)

Texto 2: (...) Leiloamos esse relógio usado pelo Faustão na estréia do Domingão. (...). (Melline e Isabelle).

Texto 1: No porão de uma velha casa do sertão de Tucano, encontraram um porta-jóias, que datava ser do séc. XVI. Dentro dele tinha um colar (...). (Carine).

\footnotetext{
${ }^{3}$ Lembremos também do princípio de cooperação proposto por Grice, que está ligado a tais fatores e explicitam claramente a relação de produção da referida atividade.
} 
Texto 2: Procura-se um belíssimo colar de ouro perdido durante o furacão Sandy.(...).(Melline e Isabelle).

Ampliando o leque de possibilidades de análise dos textos produzidos, desde as aulas que desembocaram na atividade, podemos dizer que o sucesso de um trabalho com textos está na observância do conhecimento teórico e da sua utilização, o que os pedagogos denominam de "transposição didática" e foi exatamente isso que procuramos fazer em nossas aulas, quando introduzimos conceitos, exemplificações, discussões, etc e depois sugerimos que os estudantes utilizem as teorias tornando-as "executáveis" para a melhorarem suas percepções de tais teorias, tornando-as possíveis de serem trabalhadas em suas aulas de língua.

Outro fator que podemos relacionar com o resultado da atividade sob análise é a coerência, visto que ela é responsável pelo sentido do texto, envolvendo fatores lógicosemânticos e cognitivos, já que a interpretabilidade do texto depende do conhecimento partilhado entre os interlocutores. Nos trechos destacados acima, vemos dois elementos que necessitam do conhecimento prévio dos interlocutores, no caso a localização do cenário onde se passam as narrativas e a relação dos elementos presentes no texto com o mundo real. Um texto é coerente quando as informações nele contidas são compatíveis com o conhecimento de mundo do receptor. Observar a coerência é fundamental, pois é através dela que podemos perceber que um texto constrói-se na relação emissor-receptor-mundo. Quando falamos em coerência e informatividade, que a meu ver estão intimamente ligadas, não podemos deixar de relacioná-las à situacionalidade que é a adequação do texto a uma dada situação comunicativa, pois ela orienta o sentido do discurso, tanto na sua produção como na sua interpretação.

Nesse sentido, podemos relacionar a coerência ao nível de informatividade dos interlocutores/interactantes, já que esse elemento fornece a medida pela qual as ocorrências de um texto são esperadas ou não, conhecidas ou não, pelo receptor. Nos trechos produzidos pelos meus estudantes, vemos claramente esse princípio, pois o mesmo objeto (relógio, colar, fita adesiva) foi descrito distintamente por cada pessoa/dupla, pois elas o encararam de modo diverso, já que o texto não é um simples reflexo do mundo real. O homem serve de mediador, com suas crenças e ideias, recriando a situação. Veja-se a inserção do local de nascimento de um dos estudantes (Sertão de Tucano) em contraposição com o cenário da realeza britânica, assim como a atualização de fatos recentes como o furacão Sandy ou com um programa televisivo, desencadeando no leitor a necessidade de acesso de suas informações para dar a coerência ao texto, por meio de seus conhecimentos de mundo, via leituras e vivências.

Quando cito os elementos acima, posso inserir também nessa análise o princípio da intertextualidade, pois quando se falou do furacão Sandy, enquanto leitores, tanto podemos recuperar as nossas informações sobre o ciclone extratropical que afetou alguns países ${ }^{4}$ no dia 28

\footnotetext{
${ }^{4} \mathrm{O}$ furacão Sandy foi um ciclone tropical que afetou a vida de pessoas de vários países em outubro de 2012. Foi apelidado de Frankenstorm por ter previsão de chegar ao leste do Canadá no dia das bruxas. Foi elevado à categoria de furacão em 24 de outubro de 2012, antes de entrar na Jamaica. Depois entrou no território cubano em 25 de outubro como um furacão de categoria 2. No início de 26 de outubro, estava sobre as Bahamas. No dia 27 de outubro, voltou a enfraquecer para categoria a 1 . No dia 29 de outubro, os efeitos do furacão eram sentidos na costa leste americana. Na noite do dia 29 , o furacão tocou o solo no sul de Nova Jersey, assim os efeitos passaram a ser sentidos em toda costa nordeste. Em Nova Iorque, houve alagamentos, cortes de energia para 650 mil pessoas e ventos de até $180 \mathrm{~km} / \mathrm{h}$. A umidade trazida pela tempestade e o ar frio causaram nevascas em Virgínia Ocidental,
} 
de Outubro de 2012 ou ainda pensarmos se tratar das polêmicas relacionadas à cantora, filha da dupla sertaneja "Chitãozinho e Xororó". Também vemos o intertexto nas relações estabelecidas pelos autores dos textos entre o cenário nacional e o internacional, por exemplo. Segundo Koch (2000), a intertextualidade é um importante fator de coerência, na medida em que para o processamento cognitivo de um texto recorre-se ao conhecimento prévio de outros textos.

Segundo os PCNs (1998),

A produção de discursos não acontece no vazio. Ao contrário, todo discurso se relaciona, de alguma forma, com os que já foram produzidos. Nesse sentido, os textos, como resultantes da atividade discursiva, estão em constante e contínua relação uns com os outros, ainda que, em sua linearidade, isso não se explicite. A esta relação entre o texto produzido e os outros textos é que se tem chamado intertextualidade (PCNs, 1998, p.12).

Nossa proposta de modelo, além dos componentes linguístico-discursivos descritos acima, consta de uma espécie de módulo, para melhor guiar os estudantes durante as atividades de escrita. Para tanto, ela segue sete fases complementares:

$\mathrm{Na}$ primeira fase, que se configura numa etapa diagnóstica, o aluno buscará compreender melhor o seu papel de escritor. Para tanto, será disponibilizado ao estudante o maior número possível de textos de vários gêneros, a fim de que o aluno tenha, após leituras, comentários e análises, argumentos suficientes para a realização do plano do futuro texto.

Contudo, apenas leituras e discussão não são suficientes, se o aluno não conta com material de consulta, a exemplo de bons dicionários e gramáticas. O desenvolvimento do hábito de utilizar esse tipo de material em muito resolveria as dificuldades enfrentadas pelos escritores no que concerne a ortografia e a coerência textual, visto que com a ajuda do dicionário e de uma gramática, haveria uma melhor sistematização das anotações feitas quando da revisão dos escritos, a fim de indicar onde os estudantes precisam melhorar.

A partir desses instrumentos/estratégias, o aluno poderá ampliar seu diagnóstico, fazendo uma lista de suas dificuldades mais recorrentes, tornando-as objeto de seu desafio. Para tanto, ele precisa saber em qual nível se encontra sua(s) dificuldade. Ela está no nível linguístico (concordância, regência, ortografia, pontuação, acentuação), no nível textual (ordenação dos parágrafos, fuga parcial do tema, nível argumentativo, etc.).

Nessa etapa, o aluno deverá começar a sistematizar seus conhecimentos linguísticos e textuais, a fim de saber onde, como e por que ele comete determinados erros, para saná-los e assim melhorar sua capacidade escritural. Entre outras ferramentas, ele deve estar sempre atento à necessidade de consultar um dicionário, para melhorar sua ortografia e ampliar seu léxico; uma gramática, para observar as regras e normas do bem escrever e assim melhorar sua capacidade linguística. Também deve dispor de um rico material de consulta, para os momentos em que ele não dispuser nem de dicionário nem de gramática. A seguir, ele deve anotar suas dificuldades, ordenando-as por categorias, conforme visto anteriormente.

Na segunda etapa, é o momento de explorar os textos dos pares (colegas de classe, textos de outros estudantes, publicados em fontes diversas (manuais escolares, sites, etc.), os quais

Carolina do Norte e Tennessee. Após ser rebaixado à categoria de ciclone extratropical em 29 de outubro, Sandy dissipou-se no dia 31. 
apresentem problemas linguísticos e textuais, com exemplos de correções, a fim de ajudar o aluno em suas aprendizagens). Após a leitura, análise e registro das dificuldades enfrentadas pelos pares, é hora de explorar seu próprio texto, comparando as dificuldades enfrentadas pelos pares às suas, a fim de melhor sistematizar as necessidades que o estudante possui no que concerne seu texto e o texto dos demais.

Cada pessoa tem uma maneira diferente de se comportar enquanto lê, estuda ou escreve. Nesse momento da preparação da atividade de escrita, o professor deve solicitar que o aluno anote suas estratégias, a partir de respostas às seguintes questões:

No que concerne à leitura

a) Como você escolhe um texto/livro para ler? O que o leva a essa escolha? b) Uma vez escolhido o tipo de leitura, como você a inicia? Durante a leitura, você costuma ter que tipo de atitude? Grifa certas passagens? Anota dúvidas? Faz comentários? Cite outras estratégias

No que concerne à escrita

No desenvolvimento do seu texto você costuma (solicitar que o estudante escreva as etapas que ele segue ao produzir um texto):

a) Para iniciar minha produção normalmente eu....

b) Para desenvolver minha produção normalmente eu...

c) Para finalizar minha produção normalmente eu...

\section{No que concerne às estratégias}

Utilize as seguintes propostas para melhor sistematizar suas aulas:

a) Atividades de antecipação

- Informe os objetivos das atividades;

- Forneça a informação de suporte;

- Nomeie e clarifique os conceitos a serem aprendidos;

- Motive os alunos, usando princípios relevantes;

- Apresente os resultados desejados.

b) Atividades de consolidação: ajude seus alunos a escolherem a melhor estratégia de trabalho, personalizando-a, através de questões do tipo: "Quando é que podes utilizar isto?"; Formule expectativas: "Espero que domines e uses esta estratégia até.....(marcar prazo)."; Verifique o progresso: "O que faremos quando completares esta parte?"

c) Atividades de Brainstorming: escrever um tópico e uma série de palavras, algumas claramente relacionadas ao tópico, outras que claramente não dizem lhe respeito e outras ambíguas, a fim de ampliar o léxico do aluno e ajudá-lo nas escolhas das palavras mais adequadas a serem utilizadas.

d) Atividades de modelização: exerça um natural prolongamento de perguntas do tipo: "Como é que...", além de usar modelos para expressar o seu próprio processo de pensamento. $\mathrm{Na}$ sequência, explicite e demonstre o modelo várias vezes. 
e) Atividades de Feedback: deve ser individualizado, frequente e positivo, mas também corretivo quando necessário; deve ter noções e itens claros.

Formas de feedback: correção sistemática de trabalhos, publicação; trocas entre pares.

Objetivos das estratégias: Interpretar o enunciado da questão que lhe é proposto; Estruturar a situação que lhe é apresentada; Fazer transferências de conceitos para resolver novos problemas; Descobrir relações; Desenvolver habilidades do raciocínio lógico e de argumentação, buscando questões como "o que acontecerá se...", as quais ajudam a analisar um argumento e a reconhecer argumentos válidos. (Adaptado de Fernandes, 2005).

\section{Análise e registro dos progressos}

Nessa etapa, os alunos deverão organizar seus textos por categorias, para melhor visualizarem seus progressos. Para tanto, mais do que nunca o uso de gramáticas e dicionários é fundamental, além é claro de um barema de avaliação que o professor deve disponibilizar e explicitar claramente cada dimensão desse instrumento, a fim de que os alunos possam reconhecer suas dificuldades e tentar resolvê-las. Contudo, o uso de instrumentos e de materiais de ajuda só tem razão de ser quando há um trabalho conjunto entre pares (professor alunos; alunos e seus colegas).

A cada problema detectado, o aluno deve anotá-la, considerando sua natureza: no sentido macro (forma, conteúdo, progressão, etc) ou no sentido micro (correção lingüística, coesão, coerência, etc.).

\section{Publicação das produções (feedback)}

Nossos estudantes não escrevem por vários motivos, dentre os quais a falta de hábito, a falta de motivação e, principalmente, por falta de um feedback. Lembremos as palavras de Geraldi (1980), quando ele diz que os alunos escrevem para um só interlocutor, numa ação monóloga da escola. Corroborando esse pensamento, acredito que precisamos dar sentido ao que é produzido nas escolas.

Muitas vezes, nas aulas de redação, nos deparamos com um ensino reducionista, especialmente no tocante ao gênero textual, que numa total falta de sinergia entre a macroestrutura e a micro-estrutura textual, dá-se prioridade a determinado gênero, o qual é trabalhado à exaustão numa determinada série. Na quinta e sexta séries, normalmente se ensina a narração. Na sétima série, a descrição é a "bola da vez" e, da oitava série ao terceiro ano do ensino médio, valoriza-se o texto dissertativo, sem demonstrar a importância que cada um desses gêneros tem

na relação com os demais. É possível narrar sem descrever? Um cenário se delineia sem uma história, sem conflitos, sem aprendizagens, sem argumentação? Sem nos levar a uma reflexão?

Contudo, embora haja uma dedicação total a um gênero e suas características, não há o ensino efetivo de nenhuma das modalidades textuais, pois independente da tipologia textual o aluno se depara com modelos de textos clássicos, com uma linguagem distante do seu universo. Apresentado o texto, segue-se com uma leitura, sempre guiada pelas concepções do professor, que normalmente se baseia nas questões propostas pelos manuais escolares a fim de fazer-lhe a “interpretação". Quando há uma proposta de redação acerca do tema proposto, esta geralmente segue também o modelo do manual ou do mestre, que deve seguir à risca os macetes ditados pelos processos seletivos.

Raramente o aluno recebe informações teóricas sobre como, por que e para que produzir o texto, senão para ter sucesso no vestibular! Poucas são as vezes em que o texto produzido, 
seguindo as instruções do mestre recebe um tratamento adequado, um feedback sobre o que o aluno produziu, seus pontos fortes e as necessidades de melhoria.

\section{Considerações (quase) finais}

Conforme constatado ao longo desse documento, o texto é a manifestação material de discursos, de processos linguísticos, didáticos e mentais elaborados pelos sujeitos envolvidos no ensino-aprendizagem da escrita. Nessa perspectiva, cada um dos domínios teóricos elencados no presente texto serve de suporte à complexa tarefa da escrita.

Os estudos realizados pelos domínios citados acerca da produção de texto priorizam o sujeito planejador/articulador, integrado a outros sujeitos que construirá novos textos por intermédio de uma rede complexa de fatores cognitivos-discursivos, resultante das inúmeras relações entre os interactantes implicados no processo produtivo.

Nessa perspectiva, é salutar que o professor ajude o aluno a melhor desenvolver sua capacidade de percepção da importância que a leitura tem para o seu desenvolvimento intelectual, bem como para a melhoria da sua escrita, já que devemos estar atentos quando preparamos nossas aulas de escrita, à importância da leitura para a pesquisa de ideias, para a ampliação das informações acerca dos gêneros textuais, para o conhecimento dos diferentes estilos dos demais escritores.

Para tanto, o aluno deve aprender a gostar de escrever, com o intuito de divulgar suas ideias. Entretanto, para que isso ocorra, é fundamental que ele conheça melhor a sua língua. Nesse sentido, a valorização do uso do dicionário e da gramática é fundamental para a ampliação do vocabulário bem como para o conhecimento mais formal da língua. Tais cuidados deverão auxiliar os estudantes a melhor identificarem suas forças e fraquezas no tocante às atividades escriturais.

Gostar de escrever, conhecer melhor a sua língua significa ler e escrever com mais frequência. Mas de nada adianta esse esforço sem o feedback necessário por parte do professor, que deve ler, comentar, apontar pontos fortes e dificuldades no texto do estudante da forma mais pontual possível. Nesse contexto, a função do professor de escrita é muito mais que ensinar regras gramaticais, pois a linguagem é um instrumento de interação humana, de natureza comunicativa, o que serve a produzir efeitos de sentido entre os interlocutores, num contexto que respeite os fatores de ordem cognitiva, dialógica e textual.

Se desejamos contribuir para o sucesso escolar dos nossos estudantes, uma das finalidades da nossa intervenção será a de tentar levar os alunos a desenvolverem competências diversas, através da explicitação clara da tarefa a ser cumprida, considerando seus conhecimentos anteriores, para que a representação desses conhecimentos possam ser considerados na construção de seus saberes.

Cônscia estou de que apenas um artigo não poderá fazer muito pelos nossos jovens, pois nós, acadêmicos, não vamos a campo tentar minorar a situação caótica em que se encontra a qualidade da leitura/escrita, pois estamos presos a uma redoma criada pelos nossos títulos e pelos órgãos de fomento que exigem semideuses com currículos invejáveis e, por isso mesmo, distantes da realidade das escolas.

E foi interagindo com atores sociais que como eu navegam na internet em busca de novidades, que conheci muitos textos e contextos diversos dos meus e que em muito 
contribuíram para a profissional que sou. Em algumas das minhas incursões midiáticas, depareime com discursos que bem poderiam ter sido meus, dado a justeza das suas concepções que coadunam com o que penso em relação ao valor da palavra escrita.

Nesse contexto, convoco três pensadores contemporâneos para nos fazer refletir nesse momento final do meu texto, acerca do nosso papel social, no que concerne o ensinoaprendizagem de leitura/escrita aos nossos estudantes.

Inicio pelos ensinamentos de Leffa, quando ele diz que "A riqueza da leitura não está necessariamente nas grandes obras clássicas, mas na experiência do leitor ao processar o texto. $\mathrm{O}$ significado não está na mensagem do texto, mas na série de acontecimentos que o texto desencadeia na mente do leitor" e foi exatamente isso que me levou a fazer Letras, pois acreditava que leria mais, conheceria mais, não somente para escrever artigos científicos, mas também para conhecer/refutar o mundo, ou mesmo aderir-lhe o espírito, como ensinava Perelman, já que o livro, como ensina Darcy Ribeiro “(...) é o tijolo com que se constrói o espírito. Fazê-lo acessível é multiplicar tanto os herdeiros quanto os enriquecedores do patrimônio literário, científico e humanístico, que é, talvez, o bem maior da cultura humana."

$\mathrm{Na}$ esteira filosófico-poética dessa finalização, trago ainda Caetano Veloso e sua versão acerca do papel do livro “(...) Mas os livros que em nossa vida entraram são como a radiação de um corpo negro/Apontando para a expansão do Universo Porque a frase, o conceito, o enredo o verso (e, sem dúvida, sobretudo o verso) é o que pode lançar mundos no mundo". Lancemos, pois livros, "Livros à mancheia (...)" e deixemos que os estudantes “(...) pensem, falem (...)"... escrevam, pois somente através da leitura poderemos melhorar a escrita e, consequentemente, a Educação no Brasil.

\section{Referências}

ADAM, J-M. A Linguística textual: introdução à análise textual dos discursos. $2^{\mathrm{a}}$ edição revista e aumentada. São Paulo: Cortez, 2011.

DUARTE, R. D. O papel da lingüística na formação do professor das séries iniciais: leitura e escrita. Projeto de Pesquisa/2009-2011. Faculdade de Ciências da Linguagem/Abaetetuba/UFPA.

GRICE, H. P. Logic and Conversation. In COLE, P.; MORGAN, J.L. (Eds). Sintax and demantics. vol 3. New York: Academic Press, 1975.

GREIMAS, A. J.; COURTÉ, J. Dicionário de Semiótica. (Trad. de Alceu Dias Lima e outros). São Paulo: Cultrix, 1989.

HALLIDAY, M. A. K.; HASAN, R. Cohesion in spoken and written English. London: Longman, 1989.

KOCH, I. G. V. O texto e a construção de sentidos. São Paulo: Contexto, 1997. 
HAYES, J. R.; FLOWER, LINDA, S. Identifyfing the organization of writing processes. In GREGG, L.W.; STEINBERG, E.R. (Dir.) Cognitive processes in writing: An interdisciplinary approach. Hillsdale, NJ: Erlbaum, 1980, p. 31-50.

LEFFA, V. J. Aspectos da leitura. Porto Alegre: Sagra: DC Luzzatto, 1996.

NOGUEIRA, I.; MARIA, M. Linguística Textual: da teoria para a prática em sala de aula. Disponível em: < http://www.filologia.org.br/vicnlf/anais/caderno02-02.html>.

PERELMAN, C. Le champ de l'argumentation. Bruxelles: PUB, 1997.

PORTELA, G. L. Contribuições da linguística textual para o ensino-aprendizagem da leitura/escrita. A cor das Letras. Revista do Departamento de Letras e Artes da Universidade Estadual de Feira de Santana. No 5 - 2004. p. 75 - 90.

. Ler para compreender; escrever para interagir: o papel dos processos e estratégias de escrita no ensino-aprendizagem. Diadorim (Rio de Janeiro), v. 01, p. 103-116, 2010.

A Escrita na Escola: Desafios e Propostas para o Professor de Língua e Redação. Intersecções (Jundiaí), v. 02, p. 13-41, 2012.

VAN DIJK, T. A. Cognição, discurso e interação. (Organização e apresentação de Ingedore V. Koch). São Paulo: Contexto, 1978.

VELOSO, C. Livro. CD Caetano Veloso - Faixa 2 - Livros 67.638.538. 